\title{
Abstracting the paradigm, discourse and efficacy of autonomy in higher education sector of Kerala
}

\author{
Prof K M Vishnu Namboodiri, a, * \\ ${ }^{1}$ HOD, HISTORY, Mar Thoma college, Mg University, Thiruvalla,India \\ adckmvnias@gmail.com \\ ${ }^{*}$ Corresponding author
}

Keywords: Autonomy, Kerala, UGC, World Bank, Paradigm

\begin{abstract}
Autonomy means 'self-norm' or self-determination. It basically refers to providing freedom to all people who are responsible for the execution of the job itself. A paradigm is a new way of looking or thinking about something, which is a framework containing the basic assumptions, ways of thinking, and methodology that are commonly accepted by members of a community. On the other hand, discourse is formal and orderly and usually extended expression of thought on a subject. Academic autonomy has already been materialized in selected colleges throughout the state and many more colleges are on the verge of getting autonomy. Kerala maintained a reluctant attitude in implementing autonomy in the past but suddenly, a paradigm shift is noticeable which makes the study further interesting.
\end{abstract}

\section{Introduction}

For a while now World Bank has placed Autonomy and Accountability as yardsticks of growth in higher education sector and defines Institutional autonomy as the degree of independence of the university to control itself, a condition where academic community determines how it works. Accepting for increased institutional autonomy means that government's increasingly exit from the day-to-day management of the tertiary sector, allowing universities and other higher education institutions to determine their own way and taking efforts to encourage institutions to have the freedom to making choices about their internal management and governance, provided with ideally existing market-driven incentives.

\section{The State of Affair}

The Kerala government is against granting autonomy to more colleges in the State, Minister for Education C. Ravindranath told the Kerala Assembly on 6th of March 2018, his intention was to portray the dismal state of affair with regard to Autonomy in the state of Kerala, and its reactionary stand against the commercialization of education as advocated by the central government of India in the backdrop of UGC being shut down and serious changes scheduled to hit the academic arena of the country. The UGC has the dual role of funding universities and colleges as well as to promote, coordinate and determine standards in higher education institutions. UGC's role of funding these 
institutions and quality assurance has gradually been eroded by the central government, without necessary approval of Parliament. Asserting that the government had no plans to increase the number of autonomous colleges from the present number, minister said the State government was for giving only academic autonomy to colleges and that the colleges in the State could not be compared with those in the U.S. and in the present status an three member committee is appointed to study the feasibility of continuing with or without autonomy.

Kerala is a 'role model' when it comes to education, literacy and many other yardsticks of development. Over the years the state had achieved many laurels in the arena of Human Resource Development and capacity augmentation. The steps taken by successive state governments to reform and accelerate the higher education sector have brought out mixed opinion among the academia and public at large. In the field of Higher Education some serious and drastic changes have occurred in the post LPG that makes this study pertinent and not a poor apology to serious academic and social significance, contemporary history exerts.

Autonomy means 'self-norm' or self-determination. It basically refers to providing freedom to all people who are responsible for the execution of the job itself. A paradigm is a new way of looking or thinking about something, which is a framework containing the basic assumptions, ways of thinking, and methodology that are commonly accepted by members of a community. On the other hand, discourse is formal and orderly and usually extended expression of thought on a subject.

Discourse, as defined by Foucault, refers to: ways of constituting knowledge, together with the social practices, forms of subjectivity and power relations which inhere in such knowledge and relations between them. The concept of efficacy stands for the quality of being successful in producing an intended result. The present researcher intends to study why and how the road to autonomy was taken in the Higher education sector of Kerala, expose agenda if any behind the same, possibility and challenges of a unified structure and similar pertinent questions which require both theoretical frame of reference and an explanatory coverage.

Academic autonomy has already been materialized in selected colleges throughout the state and many more colleges are on the verge of getting autonomy. Kerala maintained a reluctant attitude in implementing autonomy in the past but suddenly, a paradigm shift is noticeable which makes the study further interesting.

In Kerala, the first serious initiative in autonomous colleges dates back to 1987, when the government formed a committee of experts with dr. K. Gopalan as president to study the various aspects of the proposal to have an autonomous college in the State. The Committee recommended the creation of autonomous colleges. No follow-up action had been taken. The Inter-University Advisory Council (IUCC) was appointed in 1999 as Dr. KKN Kurup, then Vice Chancellor of the University of Calicut and Dr. Cyriac Thomas, Vice-Chancellor of the University of Kerala as Coordinator, study it and complete it with the feasibility of autonomy. Been to an affiliated college. The committee presented its report in 2000 and, even in this case, no other measure was taken.

As of 01.08.2016 there are 575 autonomous universities in the country where the neighboring state of Tamilnadu has 172 colleges, with a total of $30 \%$ of its autonomous colleague and Andhra Pradesh at 130 colleges which brings the total to $22.6 \%$. Kerala is about to be approved in 2014, with 19 colleges in three universities. The government made changes to the laws of the University in 2004 to grant them independent status to affiliated colleges.

The Government of Kerala established a Council for Higher Education in 2007, which indicated its intention to induce greater self-government through the Report on the Higher Education Policy of the State of Kerala. Kerala -2012. The association of Institutional Autonomy was mentioned in the document as a bottleneck for the implementation of any proposed and recommended reform. It is essential for the success of reform reforms in an important structural change to lead to the 
administrative organization of state universities. The report also supports complete academic and financial autonomy.

\section{References}

[1] Dahl, R. A., Shapiro, I., \& Cheibub, J. A. (2003). The democracy sourcebook. Cambridge, Mass: MIT Press.

Page 389

[2] IMF Survey: Structural Reforms Necessary, Politically Difficult http: // www. imf. Org /en /News /Articles/ 2015/

09/ 28/ 04/ 53/ sopo 1041516a

[3] Agarwal, P. (2009). Indian higher education: Envisioning the future. New Delhi: SAGE.

[4] Mathew, A. (1987): A History of Educational Development in Kerala, National Institute for Educational Planning and Administration, New Delhi.

[5] Kodoth, Praveena. GLOBALISATION AND HIGHER EDUCATION IN KERALA: ACCESS, EQUITY AND QUALITY

[6] Devasia M D. 2008. 'Pricing Higher Education: Equity vs Profit', in Meera Bai ed., Kerala Economy: Slumber to Performance, New Delhi: Serial Publications.

[7] The Challenge of Contemporary History Ramachandra Guha Economic and Political Weekly Vol. 43, No. 26/27 (Jun. 28 - Jul. 11, 2008), pp. 192-200

[8] PIERIA, John Aziz , WHAT ARE STRUCTURAL REFORMS? May 20th 2017

[9] Untangling the 'Autonomy of Higher Education Institutions', D Dhanuraj, Centre for Public Policy Research 